\title{
LOYALITAS KAUM SUFI TERHADAP SYARIAT
}

\author{
Dimyati Sajari \\ Universitas Islam Negeri (UIN) Syarif Hidyatullah Jakarta \\ Jl. Ir. H. Juanda 95, Ciputat, Jakarta, 15412 \\ E-mail: dimyatisajari@yahoo.com
}

\begin{abstract}
Loyalty Sufis against Shari'ah. In the history of Islam, the Sufis always received criticism from some scholars that they ignore the laws of Sharia. Sufis are considered more priority the inner problem than Shari'a law. This paper proves that the criticism is not always true. The majority of the Sufis still loyal and running the Shari'a law. Even many Sufis who follow the habit of the Prophet until the small things that are not considered essential. Although a small group of Sufis who ignore the law, who are a small part of the malamatiyyah, but this can not be generalized for all Sufis.
\end{abstract}

Keywords: Sufi, the Shari'a, Sufism, scholars

\begin{abstract}
Abstrak: Loyalitas Kaum Sufi terhadap Syariat. Dalam sejarah Islam, kaum sufi senantiasa mendapat kritik dari sebagian ulama bahwa mereka mengabaikan hukum-hukum syariat yang bersifat lahiriah. Kaum sufi dianggap lebih mengutamakan masalah batin daripada hukum syariat. Tulisan ini membuktikan bahwa kritik tersebut tidak selamanya benar. Mayoritas kaum sufi masih tetap loyal dan menjalankan hukum syariat. Bahkan banyak sufi yang mengikuti kebiasaan Rasulullah Saw hingga hal-hal kecil yang dianggap tidak penting. Walaupun pernah ada sekelompok kecil kaum sufi yang mengabaikan syariat, yaitu bagian kecil dari kaum malâmatiyyah, tetapi hal ini tidak dapat digeneralisir untuk semua kaum sufi.
\end{abstract}

Kata Kunci: sufi, syariat, tasawuf, ulama

\section{Pendahuluan}

Sejak dulu hingga kini tampaknya sejarah tasawuf senantiasa diwarnai dengan adanya kritik sebagian kaum ulama terhadap tasawuf dan kaum sufi. Kritik ini, seperti dikemukakan A.J. Arberry, telah terjadi sejak sejarah sufisme yang cukup dini, yaitu di era Hasan al-Bashrî. ${ }^{1}$ Kemudian kritik di era modern dan kontemporer ditunjukkan Elizabeth Sirriyeh dalam karyanya Sufis and Anti Sufis. ${ }^{2}$ Barangkali dikarenakan fakta inilah Julian Johansen menyatakan bahwa sufisme (tasawuf) merupakan khazanah spiritual dan intelektual yang paling menyita perhatian hampir di sepanjang sejarah Islam. Ia (tasawuf) senantiasa menjadi sebuah isu kontroversi. ${ }^{3}$

Naskah diterima: 5 September 2013, direvisi: 30 Oktober 2013, disetujui untuk terbit: 30 November 2013.

${ }^{1}$ A.J. Arberry, Sufism: An Account of the Mystics of Islam, (London, Unwin Paperbacks, 1979), h. 35.

${ }^{2}$ Elizabeth Sirriyeh, Sufis and Anti-Sufis: The Defence, Rethinking and Rejection of Sufism in the Modern World, (Taylor \& Francis Group: RoutledgeCurzon, 1999), h. 35.

${ }^{3}$ Julian Johansen, Sufism and Islamic Reform in Egypt: The Battle for Islamic Tradition, (Oxford: Clarendon Press, 1996), h. 1 dan Fazlur Rahman, Islam, (Chicago dan London: University of Chicago Press, 1979), h. 134.
Kritik atau kontroversi itu bermula dari sikap ulama dan penguasa, sebagaimana dikatakan Syekh Fadhlalla Haeri, yang sejak awal sejarah tasawuf tidak menaruh toleransi terhadap kaum sufi dan ajarannya. ${ }^{4}$ Menurut Johansen, kaum ulama menuduh kaum sufi menolak ibadah formal atau aspek ritual Islam. ${ }^{5}$ Haeri pun menyebutkan bahwa kaum ulama menuduh kaum sufi hanya mengurusi perkembangan batin sehingga dituduh mengabaikan hukum-hukum syariat yang lahiriah. ${ }^{6}$ Akibatnya, seperti dikatakan Arberry, hampir tidak ada sufi-sufi terkemuka yang tidak dituduh sesat, zindik atau kafir. ${ }^{7}$

Benarkah kaum sufi menolak ibadah formal atau aspek ritual Islam? Benarkah kaum sufi mengabaikan hukum-hukum syariat yang lahiriah? Tulisan ini akan

${ }^{4}$ Syekh Fadhlalla Haeri, The Elements of Sufism, (Shaftesbury, Dorset, Brisbane dll: Element, 1997), h. 77. Praktek-praktek dan teoriteori tasawuf, kata Abû Bakr al-Sirâj al-Dîn, dituduh kaum ulama tidak berasal dari era kerasulan. Dengan kata lain, tasawuf dituduh tidak otentik Islam atau tidak berasal dari Rasulullah Saw. Abû Bakr Sirâj alDîn, "The Nature and Origin of Sufism," dalam Seyyed Hossein Nasr (Ed.), Islamic Spirituality, (New York: Crossroad, 1987), h. 236.

${ }^{5}$ Julian Johansen, Sufism and Islamic Reform in Egypt, h. 1.

${ }^{6}$ Syekh Fadhlalla Haeri, The Elements of Sufism, h. 77-80.

${ }^{7}$ A.J. Arberry, Sufism: An Account of the Mystics of Islam, h. 66. 
menjawab pertanyaan ini dengan asumsi bahwa hukum syariat merupakan supremasi tertinggi dalam Islam sehingga tidak seorang pun dari umat Islam, apalagi kaum sufi, yang menolak atau mengabaikan syariat.

\section{Kritik Kaum Ulama}

Sebelum menunjukkan beberapa kritik kaum ulama terhadap tasawuf dan kaum sufi maka istilah

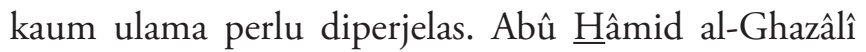
dalam kitabnya Ihŷa' 'Ulûm al-Dîn mengklasifikasi kaum ulama ini terdiri atas ahli fikih dan kaum teolog (mutakallim). ${ }^{8}$ Begitu pula dengan Fazlur Rahman yang membagi kaum ulama menjadi dua kelompok, yaitu kelompok ahli hukum dan teolog. ${ }^{9}$

Berbeda dengan al-Ghazâlî dan Rahman, Abû Nashr al-Sarrâj al-Thûsî dalam kitabnya al-Luma membagi kaum ulama itu menjadi tiga kelompok,

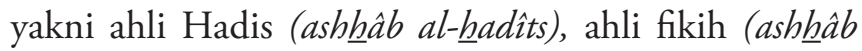
al-fuqahâ) dan para sufi. Bagi al-Sarrâj, tiga kelompok ini merupakan ulama pewaris para nabi yang ketiganya merupakan ilmuwan penegak keadilan (ulî al-îlm alqẩimîn bi al-qisth), walaupun spesialisasi ketiganya berbeda-beda. Ketiga kelompok ini, dalam pandangan al-Sarrâj, sama-sama berpegang teguh pada Kitab Allah, bersungguh-sungguh mengikuti Rasulullah Saw., meneladani para sahabat dan generasi setelahnya (al-tâbi în) serta menempuh jalan para wali-Nya yang bertakwa dan hamba-hamba-Nya yang salih. ${ }^{10}$

Walaupun demikian, ketika berbicara tentang kompetensi dan spesialisasi, al-Sarrâj menyebut istilah kaum sufi, ulama dan fukaha, yang bila penyebutan ini yang digunakan maka kategori ulama berarti hanya terdiri atas ahli Hadis. Padahal bukan pengertian ini yang dikehendaki oleh al-Sarrâj ketika dia menunjuk kelompok yang ingkar terhadap ilmu tasawuf. Menurut al-Sarrâj, orang yang mengingkari ilmu tasawuf hanyalah sekelompok dari orang-orang yang dicirikan dengan ilmu zhâhir, disebabkan mereka tidak mampu mengetahui (ilmu tasawuf ini berasal) dari Kitab Allah dan khabar Rasulullah Saw. Dalam penglihatan alSarrâj, mereka ini hanya mengetahui hukum-hukum yang zhâhir dan apa yang laik untuk dijadikan argumen untuk menghadapi orang-orang yang menentangnya. Dalam penilaian al-Sarrâj, orang-orang di masanya lebih cenderung ke sana (hukum-hukum yang zhâhir

${ }^{8}$ Abû Hâmid al-Ghazâlî, I Ihyâ' 'Ulûm al-Dîn, (Semarang: Toha Putera, t.t.), Jilid I, h. 23.

${ }^{9}$ Fazlur Rahman, Islam, h. 130.

${ }^{10}$ Abû Nashr al-Sarrâj al-Thûsî, Al-Luma', Pentahqîq dan Kata

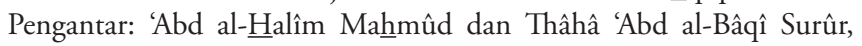
(Kairo: Maktabah al-Tsaqâfah al-Dîniyyah, t.t.), h. 22. ini) dikarenakan lebih dekat untuk mencari kedudukan dan kemegahan di mata orang awam dan lebih mudah untuk menggapai kehidupan duniawi. ${ }^{11}$

Atas dasar pandangan al-Sarrâj itu maka yang dimaksud kaum ulama dalam tulisan ini adalah sekelompok ulama ahli zhâhir yang mengkritik atau menentang tasawuf dan kaum sufi. Mungkin saja kelompok ulama ahli zhâhir ini dari kelompok ahli Hadis, ahli fikih (ahli hukum Islam), teolog atau boleh jadi dari kelompok kaum sufi sendiri. Akan tetapi dalam penelitian ini tampaknya sekelompok ulama ahli zhâhir yang dimaksud adalah yang berasal dari kelompok ulama fikih. Berikut ini beberapa contoh kritik atau kecaman sekelompok ulama terhadap tasawuf dan kaum sufi.

Di atas telah disebutkan bahwa kritik atau kecaman dari kelompok kaum ulama terhadap kaum sufi sudah terjadi pada era Hasan Bashrî (w. 110 H/728 M). Menurut Arberry, kritik atau kecaman ini dilakukan oleh Ibn Sirrin (w. 110 H/728 M), alim terkemuka pada era Hasan Bashrî. Dalam pandangan Arberry, Ibn Sirrin melakukan reaksi terhadap rumusan teori kefakiran dan pemantangan yang dirumuskan Hasan Bashrî sehingga banyak melakukan kecaman terhadap pengajaran-pengajaran dan kebiasaan-kebiasaan (hidup fakir) para zâhid dan sangat mengutuk pemakaian bulu domba (shhuf) yang dinilainya meniru pakaian Isa, sambil menegaskan bahwa dirinya lebih suka meniru Nabi Muhammad Saw yang memakai kain katun (daripada memakai bulu domba). ${ }^{12}$

Di abad berikutnya, yakni pada abad ke-3 H/9 M, kecaman atau kritik datang dari Ahmad Ibn $\underline{\text { Hanbal }}$ (w. $241 \mathrm{H} / 885 \mathrm{M}$ ) terhadap Hârits al-Muhâsibî (w. 243 H/857 M). Meski Ibn Hanbal memuji hidup zuhud dan menghargai ketulusan serta ketakwaan alMuhâsibî, tetapi ia terang-terangan mengecam metode al-Muhâsibî dalam memahami agama ${ }^{13}$ dan penggunaan Hadis yang perawi-perawinya dipandang lemah oleh Ibn $\underline{\text { Hanbal. }}{ }^{14}$ Setahun sebelum wafatnya Ibn $\underline{\text { Hanbal }}$ ini, yakni pada tahun $240 \mathrm{H} / 854 \mathrm{M}$, di Baghdad

\footnotetext{
${ }^{11}$ Abû Nashr al-Sarrâj al-Thûsî, Al-Luma', h. 33.

${ }^{12}$ A.J. Arberry, Sufism: An Account of the Mystics of Islam, h. 35.

${ }_{13}$ Majid Fakhry mengungkapkan bahwa tidak lama setelah alMuhâsibî berpindah dari Basrah ke Baghdad maka ia segera terlibat konflik dengan Ibn Hanbal dikarenakan Ibn Hanbal menentang kebebasannya menggunakan metode teologi skolastik di dalam memahami agama. Majid Fakhry, A History of Islamic Philosophy, (New York \& London: Columbia University Press, 1970), h. 265.

${ }^{14}$ Sebagai ahli Hadis, al-Muhâasibî memberikan perhatian yang besar di dalam menyusun Hadis-Hadis Rasulullah bagi ajaranajarannya. Namun Ibn Hanbal mencelanya dikarenakan al-Muhâsibî dinilainya menggunakan Hadis-Hadis yang perawinya lemah. A.J. Arberry, Sufism: An Account of the Mystics of Islam, h. 46.
} 
Dzû al-Nûn al-Mishrî dituduh telah menyelewengkan ajaran agama. ${ }^{15}$ Menurut al-Sarrâj, orang-orang yang memusuhi Dzû al-Nûn menuduhnya kafir dan zindik serta mengadukannya kepada sultan. ${ }^{16}$

Contoh berikutnya mengenai sufi yang dituduh dan diadukan ke pengusa yaitu Abû al- $\underline{\text { Hu}} u s a y n$ al-Nûrî (w. 295/908). Menurut Schimmel, al-Nûrî dituduh sebagai pelakubidah atauzindikoleh kaumortodoks dikarenakan ia mengatakan dirinya sebagai "pecinta Tuhan" (a lover of God). ${ }^{17}$ Ketika pada tahun 264 H/877 M seorang Hanbaliyyat, Ghulâm al-Khalîl, melancarkan tuduhan bidah dan mengadukan kepada khalifah beberapa sufi di Baghdad, seperti Abû Hamzah, Raqqâm, Abû Bakr al-Syiblî, al-Junayd dan al-Nûrî sendiri, maka al-Nûrî menawarkan nyawanya untuk menyelamatkan rekanrekannya yang divonis hukuman mati. Khalifah yang terkesan dengan kebesaran hati al-Nûrî mengusut perkaranya. Akhirnya Khalifah al-Muwaffaq yang mengetahui bahwa para sufi itu merupakan muwahhid sejati membebaskan mereka. ${ }^{18}$

Kemudian konflik antara kaum sufi dengan kaum ulama yang melibatkan penguasa hingga "memakan

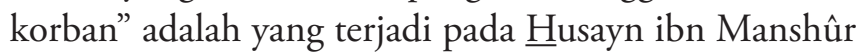

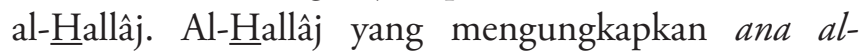
Haqq ("Akulah Kebenaran," yang kemudian hari diterjemahkan "Akulah Tuhan") diadili penguasa. Dalam persidangan yamg tidak dihadiri pengikut Hanbalî, Syâfi î̀ dan Hanafî, Qâdhî Mâlikî Abû 'Umar yang didukung sebagian besar penganut Mâlikî dan Zhâhirî menandatangani surat perintah hukuman mati al-Hallâj. Walhasil, pada tanggal 26 Maret $922 \mathrm{M}$ alHallâj dihukum mati di tiang gantung. ${ }^{19}$

${ }^{15}$ Dzû al-Nûn al-Mishrî, menurut Rahman, dipandang telah be jasa oleh kaum sufi atas usahanya mengklasifikasikan 'tahap-tahap' perkembangan spiritual. Pengklasifikasian 'jalan spiritual' ini tampaknya dianggap sebagai sebuah penyelewengan agama oleh kaum ulama karena menurut kaum ulama jika klaim-klaimm sufi diakui maka akan timbul kekacauan spiritual diakibatkan tidak mungkinnya mengatur, mengontrol bahkan meramalkan jalannya 'kehidupan spiritual' tersebut. Fazlur Rahman, Islam, h. 135.

${ }^{16}$ Abû Nashr al-Sarrâj al-Thûsî, Al-Luma', h. 498.

${ }^{17}$ Annemarie Schimmel, Mystical Dimensions of Islam, (Chapel Hill: The University of North Carolina Press, 1975), h. 60.

${ }^{18}$ Annemarie Schimmel, Mystical Dimensions of Islam, h. 60 dan Annemarie Schimmel, "Abû al-Husayn al-Nûrî: Qibla of the Lights," dalam Leonard Lewisohn (Ed.), The Heritage of Sufism: Classical Persian Sufism from its Origins to Rumi (700-1300), (Oxford: Oneworld, 1993), h. 60-1. Lihat juga Abû Nashr al-Sarrâj al-Thûsî, Al-Luma' h. 492.

19 Ahli-ahli hukum yang hadir dalam persidangan al-Hallâj ini mayoritas berasal dari aliran Mâlikî karena penganut Hanbalî, Syâfî̀ dan ahli hukum Hanafî, Ibn Buhlûl yang merupakan kepala Qâdhî Baghdad menolak menyerahkan surat keputusan mati bagi al- $\underline{\text { Hallâj}}$. Atas penolakan Ibn Buhlûl ini Abû 'Umar mengambil alih persidangan. Untuk lebih lengkapnya, baca Louis Massignon, Al- $\underline{H}$ allâj: Sang Sufi Syahid, terj. Dewi Candraningrum, (Yogyakarta: Fajar Pustaka, 2007).

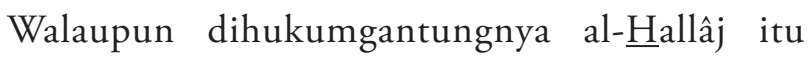
dipandang sebagai puncak konflik antara sebagian kaum ulama dan kaum sufi, tetapi konflik antar keduanya yang melibatkan penguasa masih belum berakhir. Konflik antar keduanya masih berlanjut. Para sufi mengalami nasib sebagai buruan. ${ }^{20}$ Menurut Schimmel, Abû al-'Abbâs Aḥmad ibn 'Athâ, sahabat al- $\underline{\text { Hallâj }}$ yang paling setia yang pernah saling tukar menukar surat-surat puitis dengannya, membayar persahabatan dengan nyawanya. ${ }^{21}$ Al-Sarrâj mengatakan bahwa Ibn 'Athầ ini diadukan ke sultan dengan tuduhan kafir dan zindik. Dia dipanggil perdana menteri 'Alî ibn 'Îsâ, dilarang mengajarkan ilmunya dan bahkan dibentakbentak. Ia berkata kepada 'Alî ibn 'Îsâ: "Wahai perdana menteri, bersikap sopanlah!”. 'Alî b. 'Îsâ marah. Dia memerintahkan ajudan untuk mencopot sepatu Ibn 'Athâ' dan memukulkan berulang kali ke kepalanya. Inilah, menurut al-Sarrâj, penyebab kematian Ibn 'Athâ'.22

Itulah beberapa contoh kritik atau kecaman kaum ulama terhadap kaum sufi di zaman klasik Islam. Konflik, kritik atau kecaman selanjutnya dapat dilihat dari apa yang dikatakan Haeri. Dalam penglihatan Haeri, selain al- $\underline{\text { Hallâj }}$ yang digantung pada tahun $922 \mathrm{M}$, indikasi sikap ulama dan penguasa yang tidak menaruh toleransi terhadap kaum sufi dan ajarannya adalah Yahyâ Suhrawardî yang dibunuh secara misterius di Benteng Aleppo, Suriah, pada tahun 1191 M, karya Ibn 'Arabî (w. 1240 M) dilarang pada masa hidupnya, Ibn 'Athâ' Allâh (w. 1309 M), guru tarekat Syâdziliyyât, ditentang keras Ibn Taymiyyah (w. 1328 M), Mullâ Shadrâ (w. 1640 M) dikucilkan ulama-ulama Persia pada masanya, Syaykh Maulâ al-'Arabî al-Darqawî (w. 1823 M) dipenjarakan dan Kemal Attaturk (w. 1938 M) berusaha keras melenyapkan tarekat-tarekat sufi dan tempat-tempat suci kaum sufi di Turki. ${ }^{23}$

Disamping itu, gerakan pembaharuan atau gerakan puritanisme Islam yang dipelopori oleh Muhammad ibn 'Abd al-Wahhâb (w. 1792 M) berusaha

${ }^{20}$ Kurang jelas pernyataan Schimmel "the sufis with the danger of persecution" (kaum sufi menghadapi bahaya penganiayaan) ini apakah semua sufi atau hanya pengikut al- $\underline{\text { Hallâj}}$. Annemarie Schimmel, Mystical Dimensions of Islam, h. 83.

${ }^{21}$ Menurut Schimmel, seorang sahabat lain yaitu Abû Bakr al-

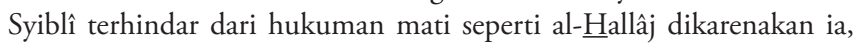
untuk menghindari hukuman mati tersebut, berperilaku 'gila' sehingga beberapa kali dirawat di rumah sakit jiwa. Ia meninggal pada tahun 945 M (23 tahun setelah kematian alenam tahun. Annemarie Schimmel, Mystical Dimensions of Islam, h. 77.

${ }^{22}$ Abû Nashr al-Sarrâj al-Thûsî, Al-Luma', h. 500. Terlepas pendapat Schimmel atau al-Sarrâj yang benar, yang jelas Ibn 'Athầ meninggal di "tangan" penguasa.

${ }^{23}$ Syekh Fadhlalla Haeri, The Elements of Sufism, h. 77. 
melenyapkan gerakan sufisme dari permukaan bumi. Walaupun gerakan ini mengikuti reformasi "musuh bebuyutan" Ibn 'Athâ' Allâh, yakni Ibn Taymiyyah, ${ }^{24}$ tetapi Ibn Taimiyyah masih mengakomodir beberapa segi ajaran tasawuf, sementara gerakan Wahhâbiyyah menyerang sufisme secara utuh. Keberhasilan gerakan Wahhâbiyyah di dalam menyerang sufisme ini dipuji M. Amin Rais. Dia menyatakan bahwa berkat jasa kaum Wahhâbî-lah pembabatan bidah, khurafat dan takhayul yang merajalela di dunia Islam pada masa lalu berhasil secara mengesankan. ${ }^{25}$ Lebih lanjut Amin Rais menunjukkan bahwa kritik terhadap sufisme itu bukan monopoli kaum Wahhâbî tetapi merupakan ciri gerakan pembaharuan sebelum abad dua puluh. Menurutnya, gerakan-gerakan pembaharuan Islam sebelum abad dua puluh memiliki kesamaan-kesamaan, di antaranya adalah melakukan kritik terhadap sufisme yang (dinilai) cenderung menjauhi tugas-tugas manusia Muslim dalam pergumulan sosial di dunia konkrit. Bahkan sufisme dianggap sebagai sebab terbesar mengapa masyarakat Islam menjadi mandek, beku, statis dan kehilangan peran serta kreativitas. ${ }^{26}$

Tampaknya pandangan kaum Wahhâbî dan pembaharu-pembaharu sebelum abad kedua puluh itu masih terasa hingga sekarang meskipun intensitasnya mungkin saja berkurang atau berbeda. Di Indonesia masih ada kelompok atau seseorang yang dewasa ini melakukan kritik atau kecaman terhadap tasawuf dan kaum sufi (di Indonesia lebih dikenal dengan tarekat). Barangkali seseorang atau kelompok di Indonesia era kontemporer ini yang melakukan kritik terhadap tarekat adalah yang sepenuhnya terinspirasi dari gerakan Wahhâbî di atas. Mungkin saja yang termasuk kelompok ini adalah Hartono Ahmad Jaiz. Dengan menukil fatwa-fatwa para ulama dari Saudi Arabia dia menyetujui bahwa tasawuf/tarekat tidak ada dasarnya di dalam Alquran dan Sunah sehingga tasawuf/tarekat divonis sebagai bidah yang sesat dan menyesatkan. Zikir berjamaah pun dianggap sebagai bidah ${ }^{27}$.

Sementara itu, Persyarikatan Muhammadiyah, yang

${ }^{24}$ Fazlur Rahman, Islam, h. 162 dan Syaikh Fadhlalla Haeri, The Elements of Sufism, h. 110. Menurut John Renard, selama karirnya di Kairo Ibn 'Athâ' Allâh lebih dua dekade terlibat perdebatan dengan Ibn Taymiyyah. John Renard, "Pendahuluan," dalam Muhammad Ibn 'Abbâd, Surat-Surat Sang Sufi, terj. M.S. Nasrullah, (Bandung: Mizan, 1993), h. 58.

${ }^{25}$ M. Amin Rais, "Kata Pengantar," dalam John J. Donohue dan John L. Esposito (Penyunting), Islam dan Pembaharuan: Ensiklopedi Masalah-Masalah, terj. Machnun Husein dari Islam in Transition, Muslim Perspectives, (Jakarta: PT RajaGrafindo Persada, 1995), Cet. Kelima,h. x-xi.

${ }^{26}$ M. Amin Rais, "Kata Pengantar," h. xii-xiii.

${ }^{27}$ Lihat buku Hartono Ahmad Jaiz, Aliran dan Paham Sesat di Indonesia, (Jakarta: Pustaka Al-Kautsar, 2002), Bab Keempat. di dalamnya Amin Rais bergabung dan pernah menjadi ketua umum, tampaknya tidak sepenuhnya diinspirasi oleh gerakan Wahhâbiyyah tersebut. Menurut Ibn Jarir, pola pikir Muhammadiyah dipengaruhi diantaranya oleh Ibn Taymiyyah, Ibn al-Qayyim dan Muhammad ibn 'Abd al-Wahhâb. ${ }^{28}$ Dengan demikian, Persyarikatan Muhammadiyah atau orang-orang Muhammadiyah tidak dapat dikategorikan sebagai kelompok yang anti tasawuf. Apalagi sang pendiri Muhammadiyah sendiri, Ahmad Dahlan, kendati di forum resmi persyarikatan tidak pernah menyampaikan tentang tasawuf tetapi ketika beliau belajar di Mekah materi tasawuf merupakan salah satu bidang yang dipelajarinya dan di setiap kesempatan selalu menekankan supaya orangorang Muhammadiyah senantiasa berpegang teguh pada akhlak karimah. Penekanan Ahmad Dahlan dan para pemimpin pengganti beliau- pada akhlak karimah ini jelas merupakan bagian dari tasawuf. Bahkan salah seorang tokoh PP Muhammadiyah, Hamka, terang-terangan mengajarkan dan menulis buku tentang tasawuf, seperti buku Perkembangan Tasawuf, Renungan Tasawuf dan Tasawuf Modern. ${ }^{29}$ Oleh sebab itu, orang-orang Muhammadiyah tidak dapat dikelompokkan ke kelompok anti tasawuf meskipun tasawuf yang diterapkan di Muhammadiyah bukanlah semua ajaran tasawuf, tetapi yang benar-benar sesuai Alquran dan Sunah.

\section{Mengabaikan Syariat}

Adanya kelompok kaum sufi yang mengabaikan syariat tidak diingkari oleh kaum sufi sendiri. Justeru inilah, menurut Rahman, yang melatari bergabungnya beberapa ulama terkemuka ke dunia tasawuf untuk menyelamatkan keadaan ${ }^{30}$. Kaum sufi yang meninggalkan syariat ini dikenal dengan sebutan kelompok malâmatiyyah ${ }^{31}$ dan tanggapan di kalangan sufi sendiri tidak sama terhadap kelompok ini. Abû 'Abd al-Rahmân al-Sulamî, seperti dinukil Trimingham, memandang kaum malâmatî sebagai hamba-hamba Allah Swt. yang derajatnya paling tinggi. Al-Sulamî menilai mereka sebagai kaum yang denyut nadinya penuh dengan kebajikan murni, benar-benar

${ }^{28}$ Ibn Jarir, "Muhammadiyah dan Tasawuf," dalam M. Amin Syukur dkk., Tasawuf dan Krisis, (Yogyakarta: Pustaka Pelajar, 2001), Cet. I, h. 181.

${ }^{29}$ Ibn Jarir, "Muhammadiyah dan Tasawuf," h. 186-195.

${ }^{30}$ Fazlur Rahman, Islam, h. 134-137.

${ }^{31}$ Malâmah (celaan, kecaman) berasal dari kata lâma-yalûmulawmân-malâman-malâmatan yang berarti mencela atau mengecam. Amatullah Amrstrong, Kunci Memasuki Dunia Tasawuf, terj. M.S. Nashrullah dan Ahmad Baiquni dari Shûfî Terminology (al-Qamûs asShûfî): The Mystical Language of Islam, (Bandung: Mizan, 1998) dan 'Alî ibn 'Utsmân al-Jullâbî al-Hujwirî, Kasyf al-Mahjûb, Is'ad 'Abd al-Hâdî Qandail (Ed.), (Kairo: Muh. Taufiq 'Uwaydhah, 1974), h. 261-265. 
tulus ikhlas dan tidak ingin orang lain akrab dengan keadaan-keadaan dan pengalaman-pengalaman ekstatik mereka. Mereka, menurut al-Sulamî, merupakan kaum sempurna yang suka menghinakan diri. Sikap lahiriah mereka, dalam pandangan al-Sulamî, tidak pernah mengungkapkan hakikat batiniah mereka sehingga mereka siap dipandang rendah oleh orang lain dan, karena itu, justeru mereka merasa dapat meleburkan dirinya dalam Tuhan. ${ }^{32}$ Adapun sufi yang melakukan kritik terhadap kelompok ini adalah al-Hujwirî, yang pendapatnya akan diungkap di bawah.

Kelompok yang banyak menimbulkan kritik dari kaum ulama itu, menurut Arberry, berawal dari "doktrin pengabaian atau ketidakacuhan" (doctrine of

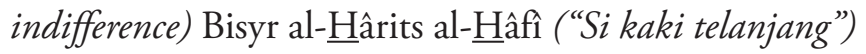
(w. 227 H/841 M). Arberry mencontohkan doktrin

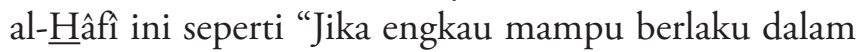
suatu situasi dimana orang-orang akan mengira engkau seorang pencuri maka dengan segala cara lakukanlah untuk menjadi begitu". ${ }^{33}$ Gerakan malâmatiyyah ini kemudian tersebar luas setelah Abû Shâlih $\underline{\text { Hamdûn ibn }}$ Aḥmad ibn 'Umârat al-Qashshâr (w. 271 H/884 M). Dia adalah seorang sufi Khurrâsân kelahiran Naisâbûr, suatu wilayah yang menurut al-Qusyayrî al-Naisâbûrî (w. 465 H/1072 M) dalam kitabnya al-Risâlah alQusyayriyyah merupakan tempat penyebaran mazhab malâmatiyyah. ${ }^{34}$ Menurut 'Alî ibn 'Utsmân al-Jullâbî alHujwirî "Al-Malâmât tark al-salâmât atau celaan adalah meninggalkan keselamatan”, merupakan ungkapan

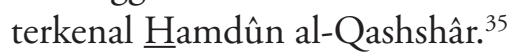

Sufi lain yang dipandang menjalani malâmah adalah Abû Yazîd al-Busthâmî (w. 260 H/874 M). Hujwirî menceritakan bahwa ketika dia memasuki suatu kota dalam perjalanan pulang dari Hijâz, masyarakat kota berlarian menemui dan mengerumuninya sebagai pertanda bahwa mereka sangat memuliakannya. Perlakuan mereka itu mengganggu Abû Yazîd dan dirasakan telah mengalihkan perhatiannya kepada Allah. Akhirnya ketika kembali dari pasar dia mengambil sepotong roti dari lengan bajunya dan memakannya. Menyaksikan Abû Yazîd makan di siang hari pada bulan

\footnotetext{
${ }^{32}$ J. Spencer Trimingham, The Sufi Oders in Islam, (London: Oxford University Press, 1971), Appendiks B.

33 Ajaran Bisyr lain yang diungkap Arberry adalah ucapannya: "Rahasiakanlah amal-amal baikmu sebagaimana engkau rahasiakan perbuatan-perbuatan kejimu”. A.J. Arberry, Sufism: An Account of the Mystics of Islam, h. 40 .

${ }^{34}$ Abû al-Qâsim 'Abd al-Karîm Hawâzin al-Qusyayrî al-Naysâbûrî, al-Risâlah al-Qusyayriyyah, (Kairo: Mathba'ah Uassân, t.t.), Jilid 1, h. 114. Hujwirî mengatakan bahwa dia merupakan ikutan kaum malâmatiyyah, syaykhnya ahli malâmatiyyah di Naisâbûr dan darinya mazhab malâmatiyyah menyebar. Abû al-Qâsim 'Abd al-Karîm Hawâzin al-Qusyayrî al-Naiâbûrî, al-Risâlah al-Qusyayriyyah, h. 263.

35 'Alî ibn 'Utsmân al-Jullâbî al-Hujwirî, Kasyf al-Mahjûb, h. 263.
}

Ramadhan itu mereka (semuanya) meninggalkan Abû Yazîd. Kemudian Abû Yazîd berkata kepada seorang murid yang menyertai perjalanannya: "Tidakkah kamu perhatikan bagaimana setelah aku meninggalkan satu masalah syariat lalu orang-orang itu semuanya menolak aku?". ${ }^{36}$ Meskipun Hujwirî menceritakan perilaku alBusthâmî ini tetapi dia membelanya dengan menyatakan bahwa waktu itu al-Busthâmî sebagai musafir sehingga diperbolehkan membatalkan puasa.

Hampir senada dengan cerita Hujwirî itu, Annemarie Schimmel juga menyebutkan sebuah kisah seorang sufi -tidak disebutkan namanya- yang melakukan perbuatan tercela (tidak pantas) yang ia kutip dari Jâmî'. Kisahnya, salah seorang sufi dielu-elukan oleh orang banyak ketika ia memasuki sebuah kota. Mereka berusaha menemui dan mengerumuni wali besar tersebut. Namun ternyata sufi itu buang air di pinggir jalan. Melihat sufi itu buang air di pinggir jalan maka mereka tidak bisa menerimanya. Oleh karena itu serta merta mereka meninggalkannya dan tidak percaya lagi bila orang itu memiliki tingkat kerohanian yang tinggi. ${ }^{37}$

Tindakan-tindakan malâmah sufi malâmatiyyah itu sebenarnya dimaksudkan untuk menyembunyikan ketulusan ketaatan mereka kepada Tuhan. Akan tetapi karena perbuatan-perbuatan itu dilakukan "untuk mendapatkan celaan" dari masyarakat umum atau orang-orang di luar kelompok mereka maka sudah tentu perbuatan-perbuatan itu dipandang tercela oleh umum. Dalam konteks hubungannya dengan kaum ulama, perbuatan tercela kaum sufi malâmatiyyah itu jelas akan mendapatkan celaan dari kaum ulama, yang pada gilirannya berandil mempertegang hubungan antara kaum ulama dan kaum sufi. Apalagi Hujwirî sendiri, sebagaimana telah dikatakan di atas, melakukan kritik terhadap kaum malâmatiyyah ini. Menurutnya, mencari malâmah termasuk perbuatan riya (perbuatan pura-pura, pamer) dan perbuatan riya itu merupakan kemunafikan. Orang yang berbuat pamer, kata Hujwirî, melakukan sesuatu agar diterima orang lain. Sedangkan kaum malâmatî melakukan perbuatan tercela agar ditolak orang lain. Kedua-duanya, dalam penilaian Hujwirî, sama-sama menaruhkan perhatiannya kepada makhluk dan tidak lebih dari itu. ${ }^{38}$

\footnotetext{
${ }^{36}$ Hujwîrî mengatakan bahwa dulu untuk mendapatkan celaan ditempuh dengan cara melakukan perbuatan 'mungkar' yang bertentangan dengan kebiasaan umum. Kini, menurut Hujwîrî, untuk mendapatkan celaan cukuplah seseorang melakukan shalat dua rakaat dengan bacaan yang sangat panjang maka orang-orang akan menyebutnya riya dan pendusta. 'Alî ibn 'Utsmân al-Jullâbî al-Hujwirî, Kasyf al-Mahjûb, h. 263.

${ }^{37}$ Annemarie Schimmel, Mystical Dimensions of Islam, h. 86.

38 'Alî bin 'Utsmân al-Jullâbî al-Hujwirî, Kasyf al-Maḩjûb, h. 261265.
} 
Kritik Hujwirî itu terlihat semakin tegas ketika mengomentari golongan malâmatiyyah yang ketiga, yang divonis Hujwirî sebagai kelompok yang benarbenar sesat, rusak dan gila. Untuk lebih memperjelas kritik Hujwirî terhadap golongan malâmatiyyah ini perlu diungkap bahwa Hujwirî mengelompokkan kaum malâmatiyyah menjadi tiga golongan, yaitu golongan yang mengikuti jalan lurus (malâmah istiqâmah al-sayr), golongan yang dengan sengaja melakukan perbuatan tercela (malâmah al-qashd) dan golongan yang dengan sengaja meninggalkan syariat (malâmah al-tark). Hujwirî menjelaskan bahwa golongan yang pertama adalah golongan yang tidak meninggalkan kewajibankewajiban agama dan praktek-praktek ibadah, hanya saja ia tidak menghiraukan orang lain (sibuk dengan perbuatannnya sendiri) sehingga ia mendapat celaan. Golongan yang kedua adalah golongan yang sengaja melakukan perbuatan tercela supaya mendapatkan celaan tetapi dia tidak melanggar hukum-hukum agama. Mereka ini adalah orang-orang terhormat yang sangat dihormati orang lain dan hati mereka pun cenderung pada kehormatan itu sehingga hati mereka terikat dengan orang lain. Akan tetapi mereka bermaksud mengosongkan hati mereka dengan orang lain dan ingin menyibukkan diri hanya dengan Tuhan. Oleh sebab itu mereka menempuh jalan celaan. Adapun golongan yang ketiga adalah golongan yang dikendalikan oleh kekafiran dan kesesatan sehingga mereka meninggalkan syariat dan tidak mau mengikutinya. Mereka berdalih "telah menempuh jalan celaan" (aslaka tharîq al-malâmah) sehingga syariat (boleh) ditinggalkan. Hujwirî menilai golongan ketiga ini sebagai kesesatan yang nyata, kerusakan yang jelas dan kegilaan yang sebenarnya. ${ }^{39}$

Barangkali terhadap kelompok malâmatiyyah yang dengan sengaja meninggalkan syariat -dengan alasan telah menempuh jalan celaan sehingga mereka beranggapan boleh meninggalkan syariat- yang divonis Hujwirî sebagai golongan yang benar-benar sesat, rusak dan gila itulah kaum ulama, sebagaimana dikatakan Arberry di atas, banyak melakukan kritik. Disamping melahirkan banyak kritik, golongan malâmatiyyah yang meninggalkan syariat ini pula yang menyebabkan seluruh gerakan tasawuf jatuh terhina. ${ }^{40}$ Kaum ulama melakukan generalisasi terhadap sufisme. Semua golongan dalam tasawuf dikecam seolah-olah sufisme berwajah serupa. Bahkan mereka seakan-akan tidak menghendaki adanya kehidupan sufisme. Sebenarnya, menurut Schimmel, persoalan malâmatiyyah ini muncul ketika orang-orang masuk menjadi anggota

\footnotetext{
39 'Alî bin 'Utsmân al-Jullâbî al-Hujwirî, Kasyf al-Maḩjûb, h. 261265.

${ }^{40}$ A.J. Arberry, Sufism: An Account of the Mystics of Islam, h. 70.
}

atau menganggap dirinya menjadi anggota tetapi tidak bersedia melaksanakan latihan malamatiyyah yang sebenarnya. Akibatnya, mereka ini melakukan hal-hal yang tidak bermoral dan menganggap enteng hukum Ilahi. Malâmatiyyah yang sebenarnya, kata Schimmel, tidak seperti mereka ini. ${ }^{41}$

\section{Syariat di Mata Kaum Sufi}

Bila Schimmel menyatakan bahwa malâmatiyyah sejati tidak memandang enteng hukum Ilahi (syariat) maka dapat dimengerti kalau hanya malàmatiyyah tidak sejati yang mengabaikan hukum Ilahi. Posisi syariat di mata kaum sufi dapat diketahui dari pandangan mereka mengenai syariat dan ketaatan atau loyalitas mereka terhadapnya.

Pandangan mengenai syariat diantaranya dikemukakan oleh al-Sarrâj. Di dalam kitabnya alLuma; al-Sarrâj mengatakan bahwa syariat adalah sesuatu yang diajarkan dari Alquran dan Rasulullah Saw. Akan tetapi tidak seperti kaum ulama yang memahami syariat itu hanya yang bersifat amal lahiriah (al-syarî‘at al-zhâhirah), al-Sarrâj -dan kaum sufi lainnya- memahami syariat itu terdiri atas dua segi, yaitu lahir dan batin tanpa melakukan pemilahan terhadap keduanya. Al-Sarrâj menjelaskan tentang dua aspek amal syariat ini. Menurutnya amal lahir adalah amal anggota badan bagian lahir (luar) dan amal batin adalah amal anggota badan bagian dalam (batin) yaitu amal hati. Al-Sarrâj memaksudkan amal lahir sebagai amal dalam bentuk ibadah-ibadah (semisal bersuci, shalat, zakat, puasa, haji dan jihad) dan hukum (seperti hukum pidana, talak, jual beli, farâ'idh dan qishâsh), sedangkan amal batin dipahami sebagai maqamât dan a hââl, semisal pembenaran, iman, yakin, jujur dan ikhlas. Bagi al-Sarrâj, ilmu atau amal yang batin tidak cukup tanpa adanya ilmu atau amal yang lahir dan ilmu atau amal yang lahir tidak cukup tanpa adanya ilmu atau amal yang batin. ${ }^{42}$ Jadi kedua ilmu atau amal ini meski dapat dibedakan tetapi saling membutuhkan, saling melengkapi dan merupakan satu kesatuan bagaikan dua sisi dari mata uang yang sama.

Dari pembagian pada aspek lahir dan batin itu maka dapat dipahami bahwa ilmu itu lahir dan batin, Alquran

\footnotetext{
${ }^{41}$ SchimmeljugamengutippandanganJâmî‘yangmempertentangkan malâmatîyyah yang taat melaksanakan ibadah dan melakukan kesalahan secara diam-diam melebihi batas semestinya dengan kaum qalandar atau darwis pengembara yang hanya melaksanakan ibadah sedikit mungkin dan menikmati kehidupan tanpa kendali. Namun, menurut Jâmî‘ sebagaimana yang dikutip Schimmel, qalandar sejati tidak seperti ini. Annemarie Schimmel, Mystical Dimensions of Islam, h. 87.

${ }^{42}$ Abû Nashr al-Sarrâj al-Thûsî, Al-Luma', h. 43-44. Lihat pula Abû Bakr Muhmmad al-Kalâbâdzî, Al-Ta'arruf li-Madzhab Ahl alTashawwuf, h. 101.
} 
itu lahir dan batin, Hadis itu lahir dan batin, dan Islam pun lahir dan batin. Al-Sarrâj membela keberadaan ilmu batin yaitu ilmunya kaum sufi dari orang yang mengingkari keberadaannya dan yang menyatakan bahwa ilmu yang dipandang berasal dari Alquran dan Sunah hanyalah ilmu syariat atau ilmu lahir. Menurut al-Sarrâj berdasarkan Alquran dan Sunah, ilmu syariat, Alquran, Sunah atau Islam itu meski tidak sama tetapi tidak bisa dipisahkan satu sama lain. Walaupun ilmu lahir dan batin itu tidak bisa dipisahkan tetapi bisa dibedakan. Di sinilah ilmu batin, yakni ilmu ahli tasawuf atau kaum sufi bisa dibicarakan tersendiri. Dengan kata lain, ilmu batin merupakan ilmu yang memiliki kekhasannya tersendiri yang membedakannya dari ilmu lahir.

Hampir senada dengan al-Sarrâj di atas, Muhammad ibn al-Fadhl al-Balkhî, sebagaimana dinukil Hujwirî, mengklasifikasi ilmu menjadi tiga, yaitu ilmu syariat, ilmu maqâmât dan ilmu makrifat. Al-Balkhî menjelaskan bahwa syariat atau ilmu syariat adalah ilmu yang berasal dari Allah Swt. ('ilm min Allâh), ilmu maqâmât (tingkatan-tingkatan spiritual) adalah ilmu bersama Allah ('ilm ma'a Allâh), yakni ilmu tentang jalan yang benar dan yang menjelaskan mengenai derajat para wali dan ilmu makrifat adalah ilmu dengan Allah ('ilm bi Allâh) yang dengan ilmu ini para wali mengenal-Nya sebagaimana Dia memperkenalkan Diri-Nya. Menurut al-Balkhî, ilmu makrifat ini tidak didapat melalui usaha karena ia merupakan hidayah dan informasi dari-Nya. Kemudian al-Balkhî menegaskan bahwa makrifat tidak akan benar tanpa penerimaan syariat (bidûni qabûl alsyarî‘ah) dan syariat tidak akan berdiri kukuh tanpa merealisasikan tahapan-tahapan spiritual (bighayr izhhâr al-maqâmât). ${ }^{43}$ Artinya ketiga ilmu ini harus ditunaikan secara bersamaan serta tidak boleh dipilahpilah dan dipisahkan.

Oleh karena itu, pemilahan dan pengintegrasian terhadap ilmu, fikih dan zuhud yang dilakukan Abû Bakr al-Warrâq perlu diperhatikan. Al-Warrâq, seperti dikutip Abû 'Abd al-Rahmân al-Sulamî, menyatakan bahwa siapa yang berilmu pengetahuan tanpa zuhud dan fikih maka dia akan menjadi zindik (tazandaqa), siapa yang zuhud tanpa ilmu dan fikih maka dia akan menjadi bidah (tabadda' $a$ ), siapa yang berfikih tanpa zuhud dan ilmu pengetahuan, maka dia akan menjadi fasik (tafassaqa) dan siapa yang mempersatukan perkara ini semuanya maka dia akan tersucikan $\left(\right.$ takhallasha) ${ }^{44}$

43 'Alî ibn 'Utsmân al-Jullâbî al-Hujwirî, Kasyf al-Mahajûb, h. 210211.

${ }^{44}$ Abû 'Abd al-Rahmân al-Sulamî, Thabaqât al-Shûfyyah, (Kairo: Mathâbi', 1380 H), h. 52.
Dalam ungkapan yang dikutip Hujwirî bahwa siapa yang merasa cukup dengan berilmu pengetahuan tanpa dibarengi hidup zuhud maka dia akan menjadi zindik dan siapa yang mencukupkan diri dengan fikih tanpa hidup warak maka dia akan menjadi fasik. ${ }^{45}$ Dengan demikian dapat dipahami bahwa ilmu, fikih dan hidup zuhud atau hidup warak, walaupun dimungkinkan untuk dibeda-bedakan dan dipisah-pisahkan, tetapi para sufi menekankan bahwa untuk mendapatkan keikhlasan yang sebenarnya pelaksanaan ketiganya harus secara bersamaan.

Dari pendapat-pendapat itu diketahui bahwa para sufi tidak meninggalkan syariat, tidak meninggalkan hukum fikih dan atau tidak meninggalkan ibadah formal, tetapi -seperti dikatakan Schimmel- justeru menjadikan hukum syariat yang bersifat lahiriah itu menjadi sesuatu yang batiniah. ${ }^{46}$ Dalam pandangan Schimmel, orang-orang sufi itu seluruhnya merupakan orang-orang Islam yang baik sebagaimana penduduk Muslim lainnya di Baghdad, Nishapur dan Mesir. Menurut Schimmel mereka tidak menolak hukum agama tetapi hanya menambahkannya dengan suatu tambahan yang menuntut pelaksanaan yang lebih ketat dalam kehidupan personal mereka. ${ }^{47}$ Orang tidak boleh lupa, tulis Schimmel, bahwa syariat sebagaimana diajarkan di dalam Alquran, diteladankan Rasulullah Saw dan diperkuat dengan kepercayaan terhadap hari pembalasan merupakan lahan yang menumbuhsuburkan keshalehan mereka. Untuk memperkuat pernyataan ini Schimmel merujuk pandangan Maulanâ 'Abd alRahmân Jâmî‘ yang menyatakan bahwa orang yang paling mengenal Tuhan adalah orang yang paling gigih melaksanakan perintah-Nya dan paling setia mengikuti tradisi Rasul-Nya. ${ }^{48}$ Dengan demikian, para sufi berkomitmen terhadap syariat, baik yang lahir maupun yang batin, atau berkomitmen terhadap Alquran dan Sunah. Al-Junayd, sebagaimana dikutip Abû al-Wafẩ al-Ghunaymî al-Taftâzânî, mengatakan bahwa siapa yang tidak hafal Alquran dan tidak menulis hadits maka dia tidak boleh dijadikan panutan dalam masalah tasawuf, sebab, menurut al-Junayd, ilmu tasawuf ini terikat dengan Alquran dan Sunah. ${ }^{49}$

Pendapat al-Junayd yang dikutip Taftâzânî itu sebelumnya pernah dirujuk al-Sarrâj. Al-Junayd, seperti dikemukakan al-Sarrâj, menginformasikan

45 'Alî ibn 'Utsmân al-Jullâbî al-Hujwirî, Kasyf al-Mahjûb, h. 211.

${ }^{46}$ Annemarie Schimmel, Mystical Dimension of Islam, h. 106.

${ }^{47}$ Annemarie Schimmel, Mystical Dimension of Islam, h. 83-84. Lihat juga pendapat Julian Baldick dalam bukunya Mystical Islam: An Introduction to Sufism, (London: I.B. Tauris \& Co Ltd., 1989), h. 18.

${ }^{48}$ Annemarie Schimmel, Mystical Dimension of Islam, h. 106.

49 Abû al-Wafầ al-Ghunaymî al-Taftâzânî, Madkhal ilâ al- 
bahwa ilmu tasawuf adalah ilmu yang terkait erat dengan Hadis Rasulullah Saw. ${ }^{50}$ Tidak seperti nukilan Taftâzânî di atas yang juga menyebutkan Alquran, tidak disebutkannya Alquran dalam kutipan al-Sarrâj ini bukan berarti al-Sarrâj memandang al-Junayd tidak menggunakan Alquran tetapi al-Sarrâj mungkin saja merasa sudah cukup dengan menyebut Hadis Rasulullah Saw. Tampaknya hal ini dapat dijelaskan dengan dua hal, yaitu: (1) Allah Swt. sudah menjamin bahwa orang yang taat kepada Rasulullah Saw berarti dia taat kepada Allah Swt. (man yuthi" al-Rasûl faqad athẩa Allâh) sehingga walaupun hanya menyebut Hadis tanpa menyebut Alquran pun dapat dipastikan bahwa dia berpegang teguh kepada Alquran. (2) Orang yang bersedia menerima Hadis otomatis dia akan menerima Alquran sehingga realitanya tidak ada kelompok yang dinamakan ingkar Alquran, tetapi kelompok ingkar Sunah atau Hadis pernah ada dalam sejarah Islam. Oleh sebab itu dapat dipastikan bahwa al-Junayd tidak mungkin ingkar Alquran.

Selain merujuk al-Junayd, al-Sarrâj pun merujuk

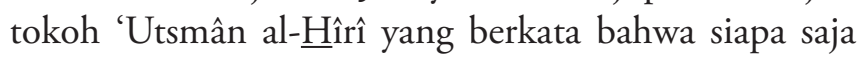
yang menjadikan Sunah sebagai pemimpin dirinya, baik secara perkataan maupun perbuatan, maka ia akan berbicara dengan penuh hikmah. Sebaliknya, siapa saja menjadikan hawa nafsu sebagai pemimpin dirinya, baik secara perkataan atau pun perbuatan, maka ia akan berbicara dengan penuh bidah. Al-Sarrâj menukil firman Allah Swt. yang artinya: "Jika kalian taat kepada Sunah maka akan mendapatkan petunjuk". ${ }^{51}$

Atas dasar itulah para sufi boleh dikatakan tidak ada yang tidak menjalankan ibadah shalat, puasa dan haji. Bahkan, seperti dikemukakan Schimmel, kewajiban ibadah ini dijadikan oleh para sufi sebagai kewajiban minimal. Atas dasar itu pula dapat dinyatakan tidak ada sufi yang meninggalkan ibadah formal. Khusus tentang ibadah haji misalnya, tidak ada sufi yang anti berhaji. Kaum sufi tidak ada yang tidak mewajibkan berhaji. Mereka berhaji dan haji dijadikan sebagai salah satu sarana bagi mereka untuk menyaksikan Tuhan. AlHallâj, umpamanya, meski pernah menyatakan bahwa menyantuni anak yatim lebih baik dibanding berhaji ke tanah suci tetapi al-Hallâj sendiri melaksanakan haji sebanyak tiga kali. Demikian pula dengan Abû Yazîd al-Busthâmî. Dia pun menunaikan ibadah haji tiga kali. Hujwirî mengungkapkan kata-kata al-Busthâmî

Tashawwuf al-Islâmî, (Kairo: Dâr al-Tsaqâfah li al-Nasyr wa al-Tawzî‘, 1983), h. 113.

${ }^{50}$ Abû Nashr al-Sarrâj al-Thûsî, Al-Luma', h. 144.

${ }^{51}$ Ayat yang dinukil al-Sarrâj ini berarti: “...dan jika taat kepadanya niscaya kamu mendapat petunjuk... (wa in tuthîûh tahtadû, Q.s. alNûr [24]: 54. Abû Nashr al-Sarrâj al-Thûsî, Al-Luma', h. 144. berkaitan dengan berhajinya ini. al-Busthâmî, seperti dinukil Hujwirî, mengatakan: "Pada haji pertama, aku hanya melihat Kabah. Pada haji kedua aku melihat Kabah dan Sang Pemilik Kabah. Di haji ketiga aku hanya melihat Sang Pemilik Kabah". ${ }^{2}$

Sementara itu, Sahl ibn 'Abd Allâh al-Tustarî dan al-Junayd al-Baghdâdî menunaikan ibadah haji satu kali. Keduanya memilih hanya berhaji satu kali atas dasar bahwa Rasulullah pun tidak pernah berhaji kecuali sekali selama hidupnya. Sedangkan sufi yang lain, semisal ㅂasan al-Qazzâz al-Dinâwârî menjalankan ibadah haji dua belas kali, Abû Bakr al-Duqqî sembilan kali, Abû Abd Allâh al-Jallâ delapan belas kali dan Ibn Khafif, guru al-Sarrâj, enam puluh kali. ${ }^{53}$

Penunaian ibadah haji oleh beberapa sufi itu menunjukkan bahwa kaum sufi -termasuk di dalamnya al-Busthâmî dan alfalsafi atau ekstatik (sukr)- tidak meninggalkan syariat, tidak meninggalkan ibadah formal dalam Islam dan tidak meninggalkan Alquran ataupun Hadis. Bahkan kaitannya dengan ittibâ' Rasulullah Saw kaum sufi mengikuti Rasulullah hingga hal-hal kecil, semisal tidak meludah ke arah kiblat dan menyela-nyelai jenggot ketika berwudu. Misalnya kisah al-Sarrâj tentang Abû Yazîd al-Busthâmî. Al-Sarrâj mengisahkan bahwa alBusthâmî mengajak muridnya mengunjungi seseorang yang dikenal banyak orang sebagai wali. Laki-laki itu banyak dikunjungi orang. Dia dikenal sebagai ahli ibadah dan ahli zuhud. Ketika (telah dekat dengan rumah orang yang disebut-sebut sebagai wali itu) orang itu keluar rumah menuju masjid dan kami melihat dia meludah ke arah kiblat. Serta merta kami berpaling darinya dan meninggalkannya tanpa mengucapkan salam kepadanya. Kami katakan bahwa laki-laki itu tidak bisa dipercaya. Dia tidak melaksanakan salah satu sopan santun (adab) diantara sopan santun Rasulullah Saw. Oleh karenanya bagaimana mungkin klaimnya tentang maqâm-maqâm kewaliannya dapat dipercaya ${ }^{54}$

Kisah tentang al-Busthâmî itu dituturkan pula

52 'Alî ibn 'Utsmân al-Jullâbî al-Hujwirî, Kasyf al-Maḩjûb: Menyelami Samudera Tasawuf, terj. Ahmad Afandi dari The Kasyf alMahjûb: The Oldest Persian Treatise on Sufism, (Jogjakarta: Pustaka Sufi, 2003), h. 384.

${ }^{53}$ Tentang penunaian ibadah haji para sufi ini lihat Dimyati Sajari, "Filantropi dalam Perspektif Sufistik", dalam Dialog: Jurnal Penelitian dan Kajian Keagamaan (Terakreditasi A), (Jakarta: Balitbangdiklat Kemenag RI, 2010), h. 65-79.

${ }^{54}$ Tampaknya cerita atau pendapat ini ditampilkan al-Sarrâj untuk menunjukkan bahwa kaum sufi itu -dalam hal ini al-Busthâmî- sangat meneladani dan mengikuti Rasulullah Saw hingga yang kecil-kecil seperti salah satu adab Rasulullah yang tidak pernah meludah ke arah kiblat. Al-Sarrâj juga menampilkan kisah al-Busthâmî lainnya yaitu tentang al-Busthâmî yang pernah berkeinginan meminta kepada 
oleh al-Qusyayrî dengan redaksi yang sedikit berbeda. Al-Qusyayrî menuturkan bahwa al-Busthâmî pernah mendatangi seseorang yang dikenal sebagai wali. Tatkala sampai di masjidnya, al-Busthâmî duduk menunggu. Orang yang ditunggu pun keluar dari rumahnya (menuju masjid) dan di masjid orang itu membuang ingus. Melihat perbuatan orang itu al-Busthâmî langsung pergi tanpa mengucapkan salam kepadanya. Al-Busthâmî mengatakan: "Orang ini tidak amanah terhadap salah satu sopan santun diantara sopan santun syariat (âdâb al-syarî́ah) maka bagaimana ia dapat dipercaya dalam hal rahasia-rahasia kebenaran?" 55

Dalam kisah itu terlihat betapa komitmennya alBusthâmî terhadap Sunah Nabi Saw sehingga persoalan meludah atau membuang ingus pun dijadikan kriteria derajat kewalian seseorang. Artinya kalau dalam hal-hal yang ringan saja seseorang tidak dapat mengikuti Sunah Nabi apalagi hal-hal yang tidak mudah. Seseorang yang tidak mampu mengikuti Sunah Nabi dalam hal yang mudah maka klaimnya dalam hal-hal yang tidak ringan seperti klaim tentang maqâmât dan a $\underline{h} w a \hat{l}$ tidak dapat dipercaya. Padahal dalam pandangan al-Qusyayrî sebagian dari syarat seorang wali adalah dia terjaga dari adab-adab syariat sebagaimana sebagian syarat seorang nabi adalah terpelihara dari segala dosa. Oleh sebab itu al-Qusyayrî menegaskan bahwa setiap wali yang perilakunya bertentangan dengan syariat maka dia terpedaya dan tertipu. ${ }^{56}$ Inilah loyalitas seorang sufi ekstatik, al-Busthâmî, terhadap syariat dan Sunah Nabi Saw hingga yang paling sederhana sekalipun.

Mengenai menyela-nyelai jenggot ketika berwudu, al-Sarrâj menginformasikan suatu kisah yang dia dengar dari Abû al-Thayyib Aḥmad ibn Muqâtil al-'Akkî alBaghdâdî yang bercerita bahwa suatu waktu dia berada di sisi Ja'far al-Khuldî di hari wafatnya al-Syiblî. Kemudian Bundâr al-Daynûrî yang merupakan pembantu al-Syiblî datang. Ja'far al-Khuldî menanyakan kepada al-Dainûrî mengenai apa yang al-Dainûrî lihat sewaktu al-Syiblî menjelang ajalnya. Al-Dainûrî memberi tahu bahwa tatkala lisan al-Syiblî sudah tidak mampu berbicara dan keringat bercucuran di keningnya, ia memberi isyarat

\footnotetext{
Allah agar Allah mencukupinya biaya makan dan memberinya isteri. Akan tetapi al-Busthâmî lalu sadar dan berkata: "Bagaimana boleh aku meminta kepada Allah dengan permintaan ini padahal Rasulullah tidak pernah meminta hal ini kepada-Nya?”. Akhirnya ia tidak jadi meminta-Nya. Namun Allah mencukupi semua kebutuhannya termasuk perempuan sehingga ia tidak peduli apakah ia berhadapan dengan perempuan atau menghadap ke tembok. Abû Nashr al-Sarrâj al-Thûsî, Al-Luma', h. 144-145.

${ }^{55}$ Abû al-Qâsim 'Abd al-Karîm Hawâzin al-Qusyayrî al-Naisâburî, al-Risâlah al-Qusyayriyyah, h. 260.

${ }^{56}$ Abû al-Qâsim 'Abd al-Karîm Hawâzin al-Qusyayrî al-Naisâburî, al-Risâlah al-Qusyayriyyah, h. 260.
}

kepada al-Dainûrî supaya al-Dainûrî mewuduinya untuk shalat. Al-Dainûrî pun mewuduinya. Namun al-Dainûrî lupa menyela-nyelakan air di janggutnya. Kemudian ia memegang tangan al-Dainûrî dan memasukkan jari-jari al-Dainûrî ke dalam sela-sela jenggotnya serta menyela-nyelakannya. Abû al-Thayyib melaporkan bahwa Ja'far al-Khuldî begitu mendengar cerita ini lalu menangis dan menegaskan bahwa apa yang laik dikatakan untuk seorang yang tidak pernah meninggalkan menyela-nyelai jenggotnya ketika berwudu hingga di saat ruhnya akan dicabut sekalipun, padahal lisannya sudah tidak mampu lagi berbicara dan keringat bercucuran di keningnya. ${ }^{57}$

Tentang men-dawâm-kan wudu atau menyucikan badan, al-Sulamî menulis tentang kisah Abû Ishâa Ibrâhîm ibn Ahmad ibn Ismâ'îl al-Khawwâsh. Tokoh ini sezaman dengan al-Junayd dan al-Nûrî. Ia wafat pada tahun $291 \mathrm{H}$. Al-Sulamî menulis bahwa ia mendengar Muhammad ibn 'Abd Allâh al-Râzî bercerita bahwa Ibrâhîm al-Khawwâsh sakit di masjid Jâmi' al-Ray. Ia susah berdiri. Ia (memaksakan diri) berdiri untuk masuk ke dalam air dan membersihkan badan lalu kembali ke masjid dan shalat dua rakaat. Kemudian ia masuk sekali lagi ke dalam air untuk membersihkan badan. Tatkala berada di tengah-tengah air itu ia wafat. ${ }^{58}$ Mungkin alSulamî mengambil kisah tentang al-Khawwâsh ini dari al-Sarrâj karena al-Sarrâj telah menceritakan kewafatan Ibrâhîm al-Khawwâsh ini dalam pembahasan tentang "Adab dalam Berwudu dan Bersuci" dan "Adab Menjelang Ajal". Menurut al-Sarrâj, al-Khawwâsh menderita sakit perut (yang menyebabkan harus berulang kali membersihkan badan). Tatkala ia telah selesai membersihkan dirinya untuk kesekian kalinya ia masuk lagi ke dalam air dan saat di tengah air inilah ia wafat. ${ }^{59}$

Sebagai pengganti wudu adalah tayamum. Bertayamum ini diperbolehkan diantaranya disebabkan sedang dalam perjalanan. Namun bila sedang atau sudah berada di kampung sendiri maka bertayamum tidak boleh dilakukan. Inilah yang disampaikan al-Busthâmî kepada seorang jamaahnya. Al-Sulamî menceritakan bahwa suatu kali al-Busthâmî mengumandangkan azan. Ketika akan mengimami shalat dia melihat dalam barisan jamaah ada seseorang yang tampak baru pulang dari perjalanan. Al-Busthâmî mendekatinya dan mengatakan sesuatu kepadanya. Kemudian lakilaki itu keluar dari masjid dan pulang. Seorang jamaah

\footnotetext{
${ }^{57}$ Abû Nashr al-Sarrâj al-Thûsî, Al-Luma', h. 145.

${ }^{58}$ Abû 'Abd al-Rahmân al-Sulamî, Thabaqât al-Shûfiyyah, h. 6768.

${ }^{59}$ Abû Nashr al-Sarrâj, Al-Luma', h. 202.
} 
ada yang menanyakan hal itu. Laki-laki itu menjawab bahwa dirinya telah melakukan perjalanan. Oleh karena dia tidak mendapatkan air maka dia bertayamum. Dia pun lupa langsung masuk masjid. Abû Yazîd berkata kepadanya bahwa dia tidak boleh bertayamum ketika telah sampai di tempat sendiri. Dia ingat hal itu kemudian pulang. ${ }^{60}$

Disamping pendapat atau amalan syaykh-syaykh sufi yang mengikuti dan meneladani Rasulullah Saw sampai hal-hal yang kecil di atas, al-Sarrâj juga menukil pendapat 'Alî al-Rûdzâbârî, Dzû al-Nûn al-Mishrî, Sahl ibn 'Abd Allâh dan Abû Sulaymân al-Dârânî tentang keterikatannya dengan syariat, Alquran dan Sunah. Al-Sarrâj menyatakan bahwa al-Rûdzâbârî berkata: "Guruku di bidang ilmu tasawuf adalah al-Junayd, guruku di bidang fikih adalah Abû al-'Abbâs ibn Surayj, guruku di bidang nahwu dan bahasa adalah Tsa'lab dan guruku di bidang Hadis Rasulullah Saw adalah Ibrâhîm al-Harbî.” Adapun Dzû al-Nûn al-Mishrî pernah ditanya: "Dengan apa engkau mengenal Allah?", Ia menjawab: "Aku mengenal Allah melalui Allah dan aku mengenal apa-apa yang selain Allah melalui Rasulullah Saw". Kemudian Sahl ibn 'Abd Allâh berkata: "Setiap wajd yang tidak dipersaksikan Alquran dan Sunah maka ia batal (tidak benar)". Terakhir, al-Sarrâj mengutip pendapat al-Dârânî yang menyatakan bahwa mungkin hatiku terisi hakikat selama empat puluh hari. Setelah itu tidak kuizinkan hakikat itu masuk ke dalam hatiku kecuali dipersaksikan Alquran dan Sunah". ${ }^{61}$

Berkaitan dengan pakaian wool, di awal tulisan ini telah dikemukakan mengenai Ibn Sirrin (w. 110 H/728 M) yang melakukan kritik terhadap pemakaian bulu domba $(s h \hat{u} f)$ yang dinilainya meniru pakaian Nabi Isa As., sambil menegaskan bahwa dirinya lebih suka meniru Nabi kita yang memakai kain katun (daripada memakai bulu domba). Berkaitan dengan hal ini, Al-Kalâbâdzî dalam kitabnya al-Ta'arruf menukil kisah tentang sahabat 'Uyaynah ibn $\underline{\text { Hishn }}$ yang mengeluh kepada Rasulullah Saw tentang abl alshuffah yang memakai bulu domba (wool). 'Uyaynah berkata kepada Nabi Saw: "Bau (pakaian wool) mereka memusingkanku. Apakah engkau tidak merasakannya?", Nabi pun menjawab: "Akan tetapi wool merupakan pakaian para nabi dan para wali”. Artinya berpakaian wool itu bukan meniru Nabi Isa As. tetapi meniru para nabi dan wali. Dengan demikian, berpakaian wool tidak melanggar syariat tetapi sesuai syariat yaitu sesuai pakaian para nabi termasuk Nabi Muhammad Saw. AlKalâbâdzî juga merujuk informasi Abû Mûsâ al-Asy'arî

\footnotetext{
${ }^{60}$ Abû 'Abd al-Rahmân al-Sulamî, Thabaqât al-Shûfiyah, h. 19.

${ }^{61}$ Abû Nashr al-Sarrâj, Al-Luma', h. 145-146.
}

yang mengatakan bahwa 70 orang Nabi yang telah melewati padang al-Rûhầ semuanya memakai mantel dan Nabi Saw pun memakai wool. Abû Mûsâ berkata: "Nabi Saw berpakaian wool, berkendaraan keledai dan mengabulkan permintaan orang-orang lemah". Hasan Bashrî menyatakan bahwa "Sungguh aku telah bertemu dengan 70 orang sahabat yang mengikuti Perang Badar. Pakaian mereka semuanya adalah wool (shûf)". ${ }^{62}$ Dalam pengertian, wool yang dipakai kaum sufi bukan berdasarkan pakaian para pendeta Nasrani (meski pendeta-pendeta Nasrani itu mungkin saja berpakaian wool) tetapi pakaian para nabi, termasuk Nabi Isa dan Nabi Muhammad Saw serta sahabatsahabat Nabi Saw. Di sini para sufi berkomitmen untuk meneladani Rasulullah Saw dan para sahabat hingga dalam hal berpakaian. Namun dikarenakan diantara para sahabat ada yang memakai pakaian bertambal, sebagaimana kisah Khalifah 'Umar ibn al-Khaththâb dan 'Alî ibn Abû Thâlib yang terkenal, maka para sufi tidak dikhususkan dengan pakaian wool saja tetapi juga pakaian bertambal. ${ }^{63}$

Berikut adalah contoh Abû Bakr ibn Dulaf ibn Jahdar al-Syiblî (247-334 H/861-946 M) dalam meneladani sahabat Abû Bakr al-Shiddîq Ra. ketika menginfakkan seluruh hartanya. Al-Sarrâj menceritakan bahwa al-Syiblî menjual kekayaannya. Dari penjualan ini ia mendapatkan uang yang banyak. Akan tetapi uang itu dibagi-bagikan seluruhnya kepada orang lain dan tidak sedikit pun ia sisakan untuk keluarganya. Oleh karena ia tidak meninggalkan sedikitpun untuk keluarganya maka banyak orang yang meributkannya. Mereka mengatakan bahwa apa yang dilakukan al-Syiblî bertentangan dengan ilmu (agama), tidak sesuai dengan larangan Rasulullah Saw untuk tidak menyia-nyiakan harta dan tidak ada imam yang bisa dijadikan teladan yang telah membagi-bagikan seluruh hartanya kepada orang lain, sementara keluarganya tidak sedikitpun mendapatkannya. Al-Sarrâj memberikan pembelaan terhadap orang-orang yang meributkannya itu dengan mengatakan bahwa imamnya adalah Abû Bakr alShiddîq Ra. yang telah mengeluarkan (menginfakkan) semua harta yang dimilikinya. Ketika Rasulullah Saw bertanya kepada Abû Bakr tentang apa yang akan Abû Bakr tinggalkan untuk keluarga maka Abû Bakr menjawab bahwa Allah dan Rasul-Nya yang akan dia tinggalkan untuk keluarganya. Rasulullah tidak mengingkari apa yang dilakukan Abû Bakr ini. Tentang pengertian menyia-nyiakan harta, al-Sarrâj menjelaskan

${ }^{62}$ Abû Bakr Muhammad al-Kalâbâdzî, Al-Ta'arruf li Madzhab Ahl al-Tashawwuf, h. 30-31.

63 'Abd al-Qâdir Ahmad 'Athâ, Al-Tashawwuf al-Islâmî bain al'Ashâlah wa al-Iqtibâs, h. 181. 
bahwa yang dimaksud menyia-nyiakan harta adalah menginfakkan harta untuk maksiat kepada Allah Swt. Dalam penafsiran al-Sarrâj, meski orang itu hanya menginfakkan seperenam dirham dari hartanya untuk maksiat kepada Allah maka perbuatannya termasuk menyia-nyiakan harta. Sebaliknya, menurut al-Sarrâj, walaupun orang itu menginfakkan hartanya seratus ribu dirham asalkan bukan untuk maksiat kepada Allah maka perbuatan ini tidak termasuk menyia-nyiakan harta. ${ }^{64}$

\section{Penutup}

Berdasarkan uraian-uraian di atas dapat disimpulkan bahwa tidak benar kaum sufi menolak ibadah formal atau aspek ritual Islam dan tidak benar bahwa kaum sufi mengabaikan hukum-hukum syariat yang lahiriah.

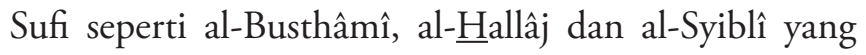
dipandang sebagai sufi falsafi saja tidak meninggalkan syariat, tidak meninggalkan ibadah formal dalam Islam dan tidak meninggalkan Alquran ataupun Hadis, apalagi sufi-sufi akhlaki, semisal al-Muhâsibîi, al-Junayd, al-Qusyayrî dan al-Ghazâlî. Bahkan kaitannya dengan ittibâ' Rasulullah Saw kaum sufi mengikuti Rasulullah hingga hal-hal yang kecil, semisal tidak meludah ke arah kiblat dan menyela-nyelai jenggot ketika berwudu.

Memang diakui bahwa pernah ada kelompok kecil kaum sufi yang mengabaikan syariat yakni bagian kecil dari kaum malâmatiyyah. Akan tetapi pernah adanya kelompok kecil kaum sufi yang meninggalkan syariat ini tidak boleh dijadikan dasar untuk mengeneralisir terhadap keseluruhan kaum sufi. Faktanya, mayoritas terbesar kaum sufi loyal terhadap syariat. []

\section{Pustaka Acuan}

Arberry, A.J., Sufism: An Account of the Mystics of Islam, London, Unwin Paperbacks, 1979.

Amrstrong, Amatullah, Kunci Memasuki Dunia Tasawuf, terj. M.S. Nashrullah dan Ahmad Baiquni dari Shîfî Terminology (al-Qamûs as-Shûfî): The Mystical Language of Islam, Bandung: Mizan, 1998.

Fakhry, Majid, A History of Islamic Philosophy, New York \& London: Columbia University Press, 1970.

Ghazâlî, al-, Abû Hâmid, I $\underline{h y a ̂ ' ~ ' U l u ̂ m ~ a l-D i ̂ n, ~ J i l i d ~ I, ~}$ Semarang: Toha Putera, t.t.

Haeri, Syekh Fadhlalla, The Elements of Sufism, Shaftesbury, Dorset, Brisbane dll: Element, 1997.

Hujwirî, al-, 'Alî ibn 'Utsmân al-Jullâbî, Kasyf al-

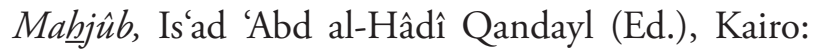

\footnotetext{
${ }^{64}$ Abû Nashr al-Sarrâj al-Thûsî, Al-Luma' h. 483.
}

Muh. Taufiq 'Uwaydhah, 1974.

-.----, Kasyf al-Mahjûb: Menyelami Samudera Tasawuf, terj. Ahmad Afandi dari The Kasyf al-Mahjûb: The Oldest Persian Treatise on Sufism, Jogjakarta: Pustaka Sufi, 2003.

Ibn Jarir, "Muhammadiyah dan Tasawuf," dalam M. Amin Syukur dkk., Tasawuf dan Krisis, Yogyakarta: Pustaka Pelajar, Cet. I, 2001.

Jaiz, Hartono Ahmad, Aliran dan Paham Sesat di Indonesia, Jakarta: Pustaka Al-Kautsar, 2002.

Johansen, Julian, Sufism and Islamic Reform in Egypt: The Battle for Islamic Tradition, Oxford, Clarendon Press, 1996.

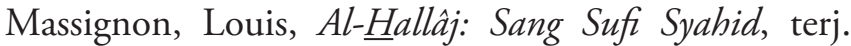
Dewi Candraningrum, Yogyakarta: Fajar Pustaka, 2007.

Qusyayrî, al-, Abû al-Qâsim 'Abd al-Karîm Hawâzin, al-Risâlah al-Qusyayriyyah, Jilid 1, Kairo: Mathba'ah Uassân, t.t.

Rahman, Fazlur, Islam, Chicago dan London: University of Chicago Press, 1979.

Rais, M. Amin, "Kata Pengantar," dalam John J. Donohue dan John L. Esposito (Penyunting), Islam dan Pembaharuan: Ensiklopedi Masalah-masalah, terj. Machnun Husein dari Islam in Transition, Muslim Perspectives, Jakarta: PT RajaGrafindo Persada, Cet. Kelima, 1995.

Renard, John, "Pendahuluan," dalam Muhammad Ibn 'Abbâd, Surat-Surat Sang Sufi, terj. M.S. Nasrullah, Bandung: Mizan, 1993.

Sajari, Dimyati, "Filantropi dalam Perspektif Sufistik" dalam Dialog: Jurnal Penelitian dan Kajian Keagamaan (Terakreditasi A), Jakarta: Balitbangdiklat Kemenag RI, 2010.

Sarrâj, al-, Abû Nashr, Al-Luma; Pentahqî̀ dan Kata

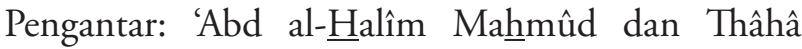
'Abd al-Bâqî Surûr, Kairo: Maktabah al-Tsaqâfah alDîniyyah, t.t.

Schimmel, Annemarie, Mystical Dimension of Islam, Chapel Hill: The University of North Carolina Press, 1975.

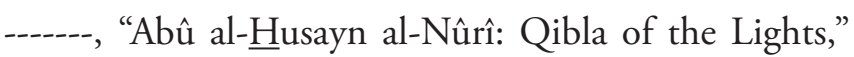
dalam Leonard Lewisohn (Ed.), The Heritage of Sufism: Classical Persian Sufism from its Origins to Rumi (700-1300), Oxford: Oneworld, 1993.

Sirâj al-Dîn, Abû Bakr, "The Nature and Origin of Sufism," dalam Seyyed Hossein Nasr (Ed.), Islamic Spirituality, New York: Crossroad, 1987. 
Sirriyeh, Elizabeth, Sufis and Anti-Sufis: The Defence, Rethinking and Rejection of Sufism in the Modern World, Taylor \& Francis Group: RoutledgeCurzon, 1999.

Sulamî, al-, Abû 'Abd al-Rahmân, Thabaqâtal-Shûfiyyah, Kairo: Mathâbi', 1380 H.
Taftâzânî, al-, Abû al-Wafầ al-Ghunaymî, Madkhal ilâ al-Tashawwuf al-Islâmî, Kairo: Dâr al-Tsaqâfah li alNasyr wa al-Tawzî́, 1983.

Trimingham, J. Spencer, The Sufi Oders in Islam, London: Oxford University Press, 1971. 